\title{
A clinical-statistical study on COVID-19 infection and death status at the Alshifaa Healthcare Center/ Baghdad
}

Rasha Raheem ${ }^{1}$, Mohammed Kadhom ${ }^{2} \odot$, Noor Albayati ${ }^{3}$, Enas Z. Alhashimie ${ }^{4}$, Wathik A. Alrubayee ${ }^{5}$, Israa Salman ${ }^{6}$, Nany Hairunisa ${ }^{7}$ and Emad Yousif $^{8}[$

\author{
Alkarkh Health Directorate, Baghdad, Iraq \\ ${ }^{2}$ Department of Environment, College of Energy and Environmental Science, Alkarkh University of Science, Baghdad, Iraq \\ ${ }^{3}$ Department of Science, College of Basic Education, University of Wasit, Azezia, Wasit, Iraq \\ ${ }^{4}$ Department of Chemistry, College of Science, Al-Mustansiriyah University, Baghdad, Iraq \\ Alshifaa Center, The Medical City, Baghdad, Iraq \\ College of Science, Al-Nahrain University, Baghdad, Iraq \\ Department of Occupational Medicine, Faculty of Medicine, Trisakti University, Jakarta, Indonesia \\ Department of Chemistry, College of Science, Al-Nahrain University, Baghdad, Iraq
}

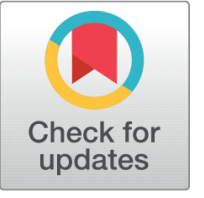

Received 20-07-2021

Revised 15-09-2021

Accepted 25-09-2021

Published 03-12-2021

\section{Corresponding Author}

Emad Yousif

emad_yousif@hotmail.com

DOI https://doi.org/10.47419/

bjbabs.v2i04.71

Pages: 218-229

Distributed under the terms of the Creative Commons

Attribution-NonCommercial 4.0 International (CC-BY-NC 4.0), which permits use for any non-commercial purpose, distribution, and reproduction in any medium, provided that the original work is properly cited.

Copyright: (c) 2021 Rasha Raheem, Mohammed Kadhom, Noor Albayati, Enas Z. Alhashimie, Wathik A. Alrubayee, Israa Salman, Nany Hairunisa, Emad Yousif

\section{ABSTRACT}

Background: COVID-19 is an ongoing disease that caused, and still causes, many challenges for humanity. In fact, COVID-19 death cases reached more than 4.5 million by the end of August 2021, although an improvement in the medical treatments and pharmaceutical protocols was obtained, and many vaccines were released.

Objective: To, statistically, analyze the data of COVID-19 patients at Alshifaa Healthcare Center (Baghdad, Iraq).

Methods: In this work, a statistical analysis was conducted on data included the total number, positive cases, and negative cases of people tested for COVID-19 at the Alshifaa Healthcare Center/Baghdad for the period 1 September - 31 December 2020. The number of people who got the test was 1080, where 424 were infected and the rest of them were not.

Results: The study showed that males' infection and death cases were higher than females by more than double, despite the population ratios of the two genders being almost equal. Furthermore, as the age of patients is older, the chance of death is higher. Death cases were lower in December than the previous three months, which could be attributed to lower infection cases compared with the previous months. Conclusions : We can conclude that the peak of infected ages was the same as the other countries. Hence, the number of checked children was low, while we have the peak around the 40s and 50s. Females' death cases were much less than males, which could be attributed to the genetic influence and the higher responsibility that females showed than males to prevent the disease's spreading.

\section{OPEN ACCESS}

Keywords ACE-2, coronavirus, COVID-19, SARS-CoV-2, transmissible diseases 


\section{INTRODUCTION}

The continuous spreading of the recent highly contagious coronavirus disease "2019 novel coronavirus or 2019-nCoV (COVID-19)" is driving the world to a very distressing stage. The disease has severe adverse effects on the world's economy, human life aspects like employment and education, and physical and mental health of individuals. ${ }^{1}$ However, the source of the virus was not discovered yet, but it is anticipated to be transmitted from animals. Since this virus belongs to the corona virus family, it was called SARS-CoV-2, where the first SARS-CoV-1 virus was discovered in 2003. ${ }^{1,2}$ The recent virus, SARS-CoV-2, main issue is its high transmission rate, which resulted in an out-of-control pandemic. ${ }^{2}$ As the numbers of infection and, definitely, mortality increased, governments declared lockdown on factories, transportations, schools, and any other gathering places, as an attempt to stop the infection. ${ }^{3}$ Unfortunately, not all countries succeeded in these attempts; in fact, the overall situation shows that these regulations were not enough and the virus continues spreading. ${ }^{4}$

After one year of its detection, SARS-CoV-19 had a modification when genetic mutations occurred and resulted in a new type of it named novel coronavirus. This was not the only change in the virus structure, where a continuous modification is occurring and new versions of the virus are mutating. However, it was noticed that SARS-CoV-2 affects children's health in much less order than other age categories. In fact, as much as the age increases, the possibility of having severe illness conditions and death increases. ${ }^{2}$

Different protocols of therapy were used to treat COVID-19 patients; these included different types of medications, practices, types of food and herbs, etc. ${ }^{3,4}$ As a result, the mortality rate decreased gradually comparing with the first period of the disease spreading. These treatment methods were accompanied with developing many vaccines from different countries and companies, where a tough competition was undertaken to come up with a solution for this pandemic. ${ }^{5}$ Recently, many vaccines were certified, although there is a doubt about their total performance and future side-effects. Many people got COVID-19 vaccines, one or two shots, and it is anticipated to have a decrease in the infection and mortality rates. ${ }^{6}$

Previous works aimed to document the health situation in Iraq and the challenges that faced the country at the beginning of the pandemic. However, strains of SARS-CoV-2 were associated with various degrees of severity, from flu-like symptoms to death, where recently high virulent strains appeared. Yet, the pathogenesis of these deadly epidemics is unclear. ${ }^{2,7-9}$ In our previous work, data were analyzed from the Alshifaa center in Baghdad from April to May 2020. ${ }^{9}$ In this work, the data of COVID-19 cases reported from the Alshifaa center in Baghdad for the period 1/Sep-31/Dec 2020 are reported. We studied COVID-19 cases in one of Iraq's COVID-19 centers to provide a brief summary of the epidemiology and history of SARS-CoV-2. The other aim was to review the epidemiology, pathogenesis, and clinical characteristics of patients infected with SARS-CoV-2 to better understand this deadly coronavirus and suggest prevention, treatment, and management strategies. It is worth mentioning that by the beginning of Jun 2021, the number of cases 
has dramatically increased in Iraq, and now more than $2 \mathrm{~K}$ cases are recorded daily. Also, death cases had the same behavior.

\section{METHODOLOGY}

The total cases of COVID-19 were collected from Alshifaa Center in Al-Rusafa side of Baghdad, which is located in the Medical city, for the period September 1 to December 31. At that period, 1080 individuals did the COVID-19 PCR test that divided into 656 negative and 424 positive cases. However, among the positive cases, 164 death cases were recorded. The study covers the period that started in late summer when it is hot, and ended in the middle of winter when it is mild cold.

To obtain realistic outcomes, it is necessary to understand the population's age categories. Data of population were acquired from the ministry of planning and graphed in Figure 1. It was reported that males and females' ratios in Iraqi society are $50.5 \%$ and $49.5 \%$, respectively. Moreover, $70 \%$ of the population live in the cities, and $30 \%$ are in the rural areas. ${ }^{10}$

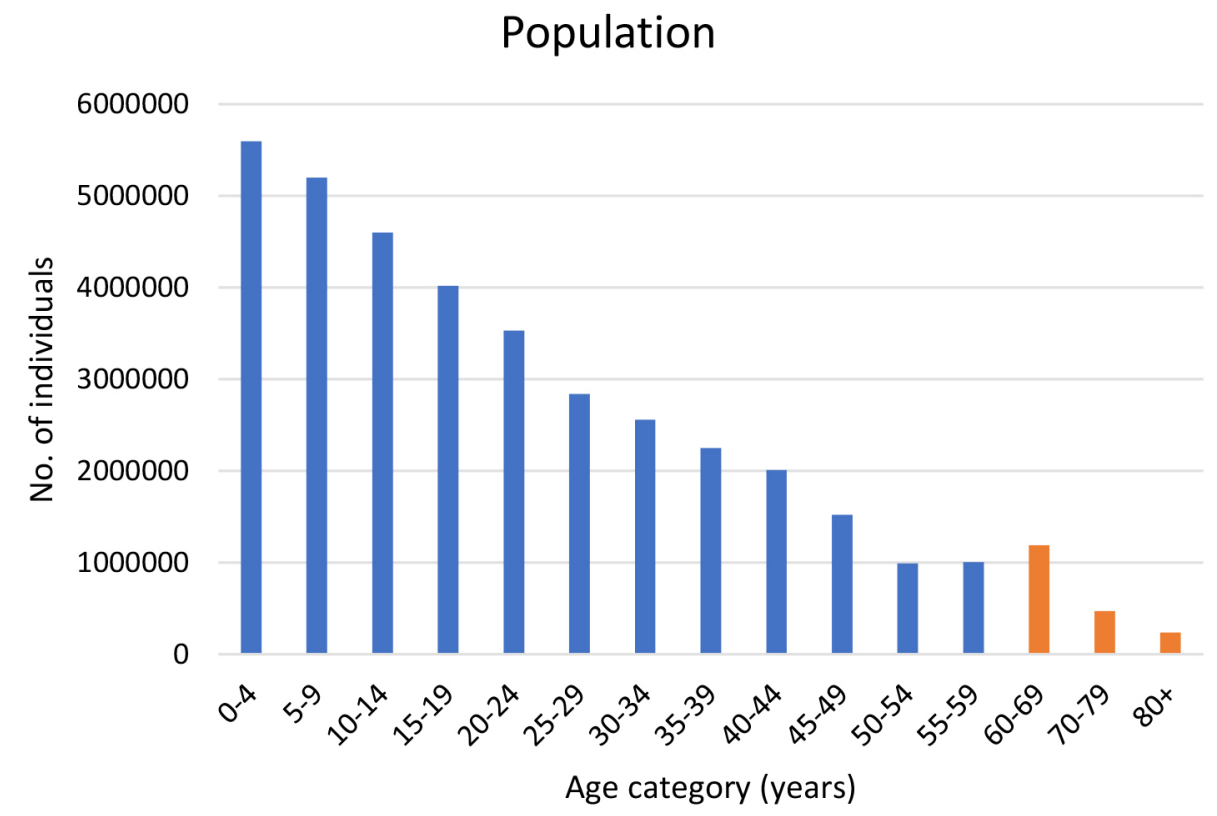

Figure 1 Population distribution according to the age categories.

For statistical analysis, t-tests were used for the determination of statistical significance. $P<0.05$ was selected as the level of significance. Data are expressed as means \pm SEM. Data are displayed as grouped-plot summary data and Column Scatter plot. All calculations were performed using Excel and Prism Plot Software. Figure 2 shows the detailed statistics of the cases 


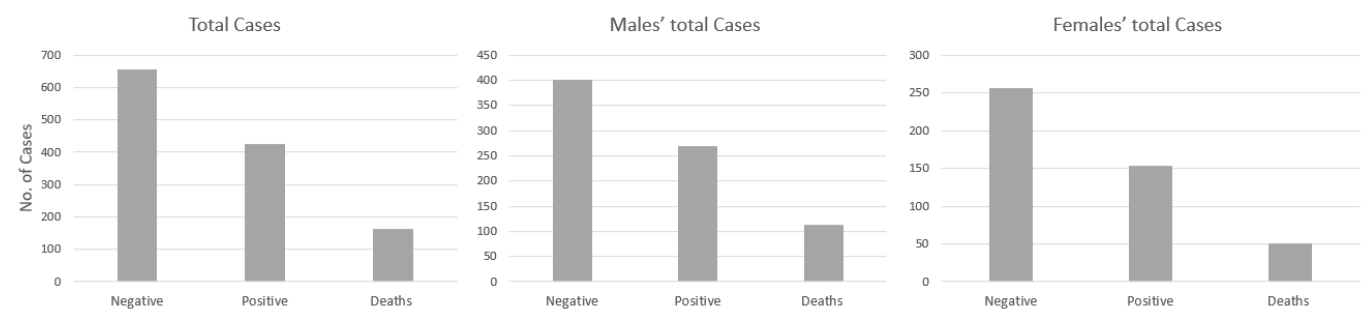

Figure 2 Total suspected people who tested for COVID-19 virus at Alshifaa Center.

\section{RESULTS AND DISCUSSION Type of cases}

The total number of patients who had the COVID-19 PCR test at the Alshifaa Center from September 1 to December 31, 2020; was 1080, divided into 670 males and 410 females. Among the 670 males, 400 were negative, 270 positive, and 114 out of the 270 positive cases ended with death. While among the 410 tested females, 256 were negative, 154 were positive, and 50 died. By dividing the number of positive cases on the total number of tests of each gender, the ratios of males and females are $40.3 \%$ and $37.6 \%$, respectively. From these numbers, it can be noticed that males had a slightly higher ratio of infection than females. It is good to mention that the number of males in Iraq society is marginally higher than females based on data from the Ministry of Planning ${ }^{10}$ (50.5\% males and $49.5 \%$ females).

Figure 3 shows the age distribution of all patients, males, and females cases. The distribution of positive cases has the bell shape, where the patients of 45 years and older showed the highest rate of infection compared to other age categories. The same behavior can be seen in both male and female graphs. The age and gender distributions are not so different from the overall distributions, where those show that males are more susceptible to COVID-19 infection than females. Furthermore, the elderly people had infection rates higher than the younger generations. ${ }^{11,12}$

Similar results are reported in many publications, where children are "more likely" expected to have a mild or asymptomatic infection. ${ }^{13,14}$ The scientists revealed that the mild to asymptomatic infection happened due to many facts: first, the expression of SARS-CoV2 , Angiotensin-converting enzyme 2 (ACE-2), within the nasal epithelium is lower in the younger age groups. ${ }^{15}$ Second, higher levels of cross-neutralizing antibodies can be found in children. Third, interleukin-6 (IL-6) and tumor necrosis factor type alpha (TNF- $\alpha$ ) are low produced. The limitation in the inflammatory response is assigned to the immature $\mathrm{B}$ and T-cells, and higher regulatory T-cell response in the childhood age. ${ }^{16}$ However, adults could get severe to deadly symptoms due to the mature immune system and IL- 6 and TNF$\alpha$ proinflammatory cytokines production, resulting in cytokine storms that cause organ injury. Moreover, the spike protein (S) of the COVID-19 virus enhances the entry into human cells via Fc receptors. As a result, elderly people may be even more susceptible to COVID-19 because they have more afucosylated IgG, which has a higher affinity with Fc 
$\underline{A}$

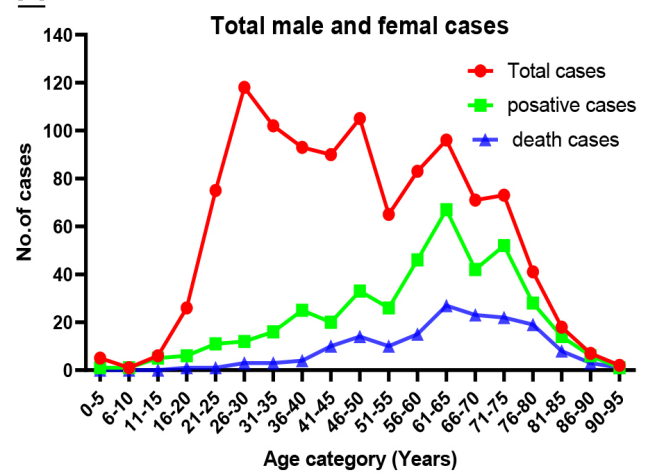

$\underline{\mathrm{C}}$

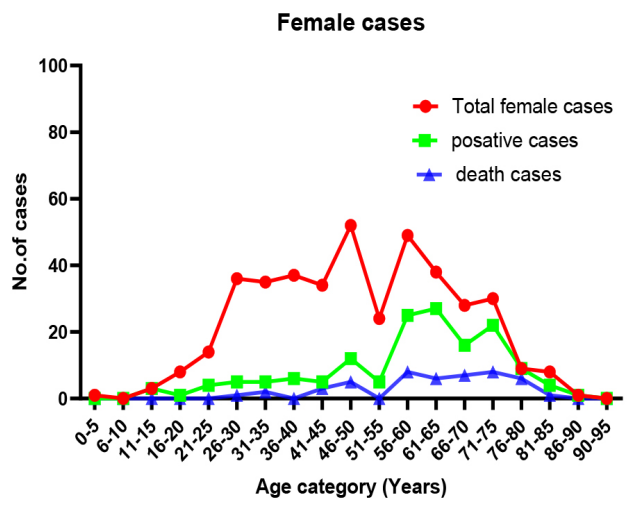

B

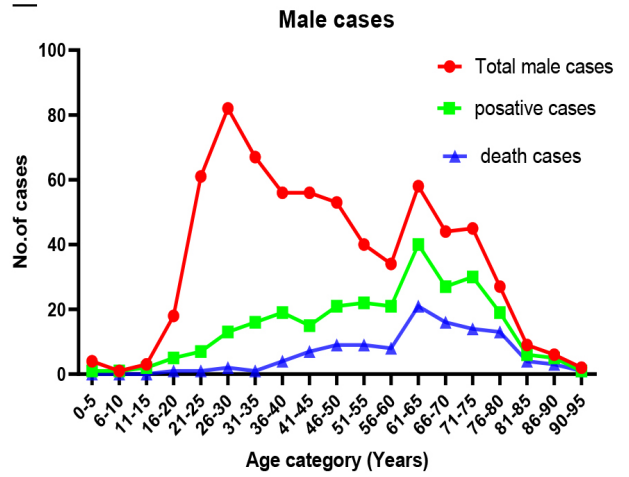

Figure 3 Age distribution of Alshifaa Centers' patients. A) total cases, B) male cases, and C) female cases.

receptors. $^{17}$

\section{Death cases}

By analyzing the death cases data, it can be noticed that as the age increases, the probability of death gets higher. Although the highest number of death cases was at the age category of 61-65 years as shown in Figure 4, the numbers of the older categories were higher due to their lower population. Here, the death cases of males were 114, while females' cases were 50. By considering the positive numbers of both genders, males were higher than females. In order to obtain a realistic comparison, the numbers of death cases were divided on the positive cases numbers; calculations showed that the males and females ratios were 42.22 and 32.5 , respectively. Hence, it can be concluded that males tend to die by $23 \%$ more than females, Figure 5 shows the cases number.

By analyzing males' death cases that are presented in Figure 6, it can be noted that the age categories of 46-60 years had similar death rate ratios, keeping in mind the variation in population numbers. However, a remarkable raise is noticed in the 61-65 years category, 


\section{Death cases}

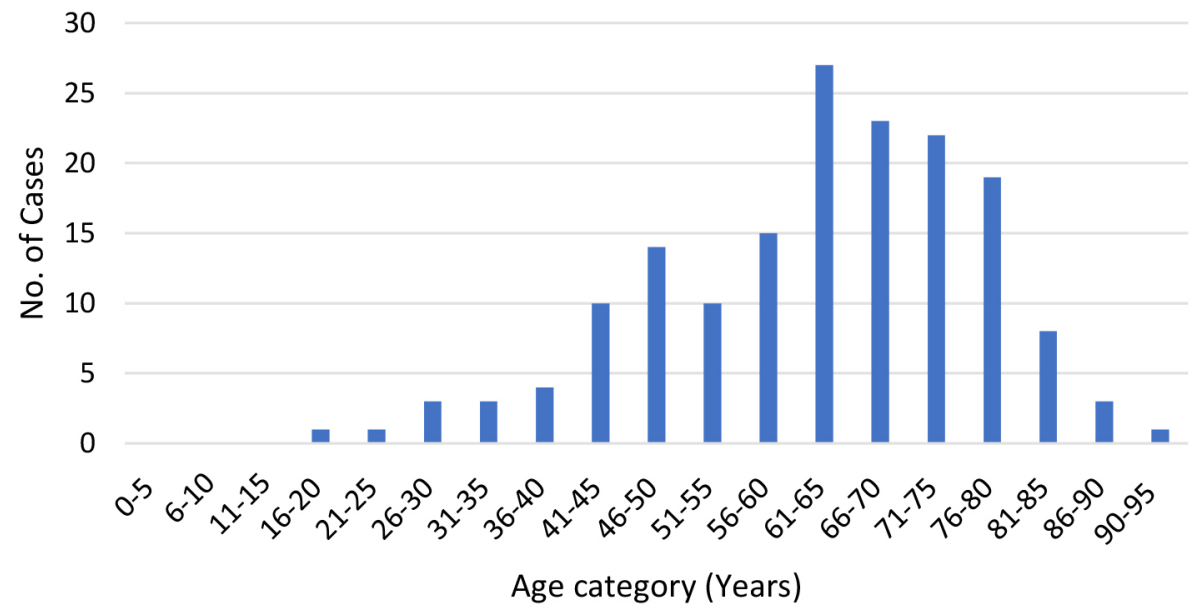

Figure 4 Age distribution of total death cases number for COVID-19 patients at Alshifaa Center.

\section{Death Cases}

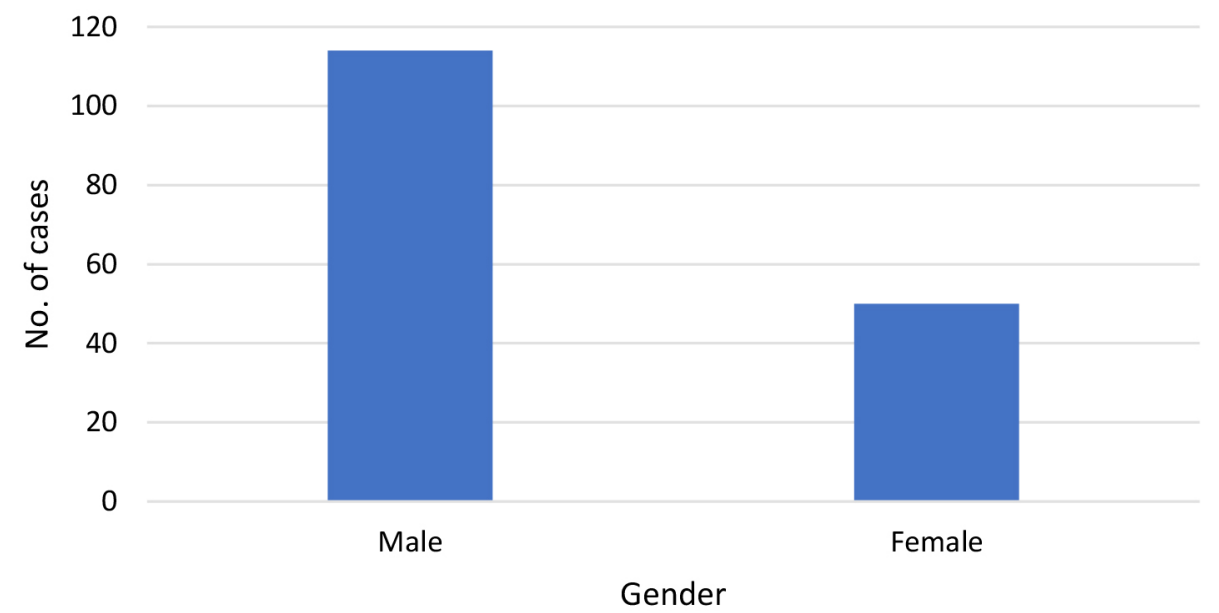

Figure 5 Male vs. female death cases numbers of COVID-19 patients at Alshifaa Center.

where this age could be more susceptible to develop severe illness symptoms and death because of COVID-19. The higher age categories were lower in Figure 6 but almost the same, or higher, when divided on the population numbers. Similarly, the age category 51-56 years of females showed a remarkable increase in death cases as shown in Figure 7. However, the death distribution of females was different from males. It can be noticed that another raise occurred in the age category 71-80 years, although the population is less, which means a higher prospect to die. This could indicate that women aging 71-80 years have a higher 
probability to die than males of the same age.

\section{Males' Death Cases}

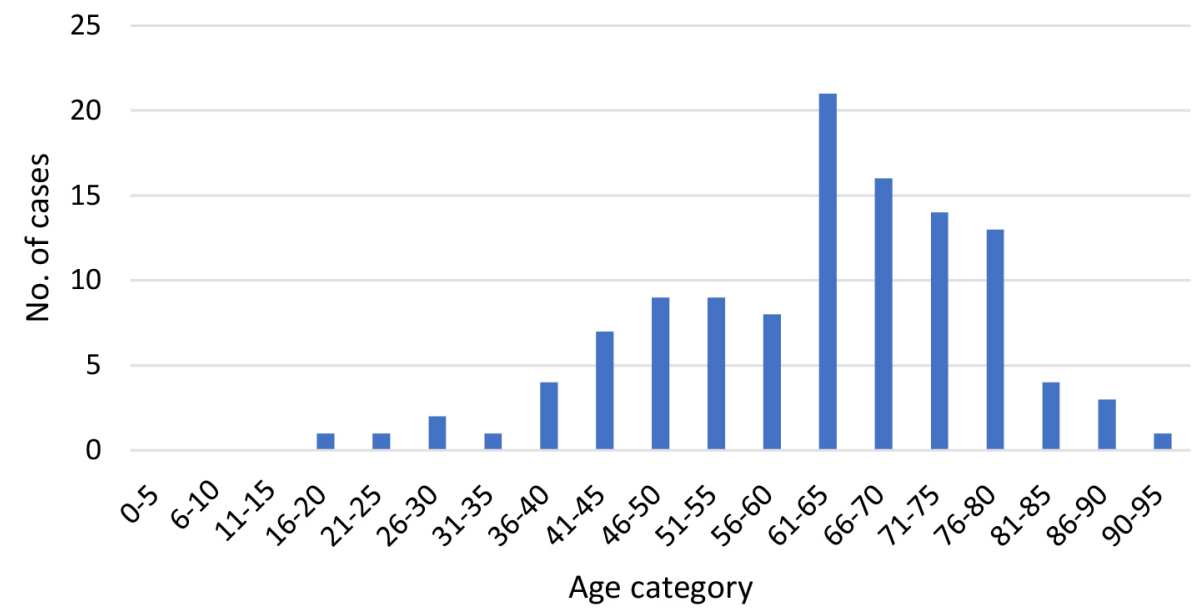

Figure 6 Age distribution of males' death cases number of COVID-19 patients at Alshifaa Center.

Figure 6 Age distribution of mas' death cases number of COVID-19 patients at Alshifaa Center:

\section{Females' Death Cases}

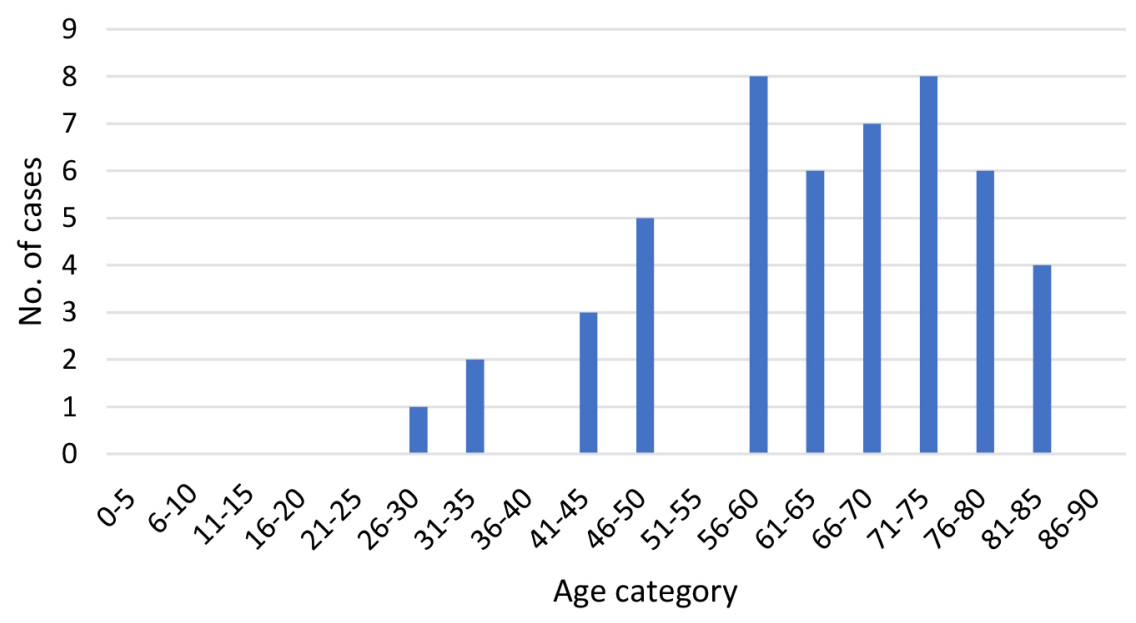

Figure 7 Age distribution of females' death cases number of COVID-19 patients at Alshifaa Center.

In a previous analysis of data obtained from the Alshifaa center; ${ }^{9}$ we also concluded that males had a higher tendency to die than females. Our finding was not away from other studies, ${ }^{6}$ and the explanation of this occurrence was attributed to the sex hormones and genetic differences. In other words, the estrogen receptors block and decrease the infection rate in females. Another reason could be the coronavirus receptor (ACE-2), which could be 
affected by men's hormones, ${ }^{18,19}$ where the ACE-2 hosts the SARS-CoV-2 and binds with when the virus enters the human cells. ${ }^{20}$ The ACE-2 is existing in different organs cells, such as the epithelial cells of the lung alveolar, small intestine enterocytes, and smooth muscle cells. $^{21}$ The ACE- 2 is also found in cardiomyocytes cells, cardiac fibroblasts, and coronary endothelial cells in heart failure cases. ${ }^{22,23}$ It is good to mention that the ACE-2 is higher in healthy, renal disease, and diabetic men compared with women. ${ }^{24}$

\section{Death cases distribution with time}

The study was conducted for four months in 2020; namely: September, October, November, and December. This period is considered as the end of summer, the fall, and the beginning of winter. From Figure 8, it can be noticed that the number of mortality cases increased gradually from September to November but decreased in December, where the lowest death cases were recorded. These findings are attributed to the decrease in the infection cases, which is in the same context with the global infection data from the worldometers website. Iraq showed a decrease in the infection and mortality rates during December 2020 and January 2021; later, unfortunately, these rates increased fast and the highest infection rates were recorded since the beginning of the pandemic.

At the beginning of March 2021, the first batch of COVID-19 vaccines arrived in Iraq. Since then, people have started getting vaccines, which could decrease the infection and mortality rates. It was anticipated to have a decrease in these rates in the next period if people get the vaccine, but the reverse scenario happened because people didn't consider vaccination seriously.

\section{Death Cases}

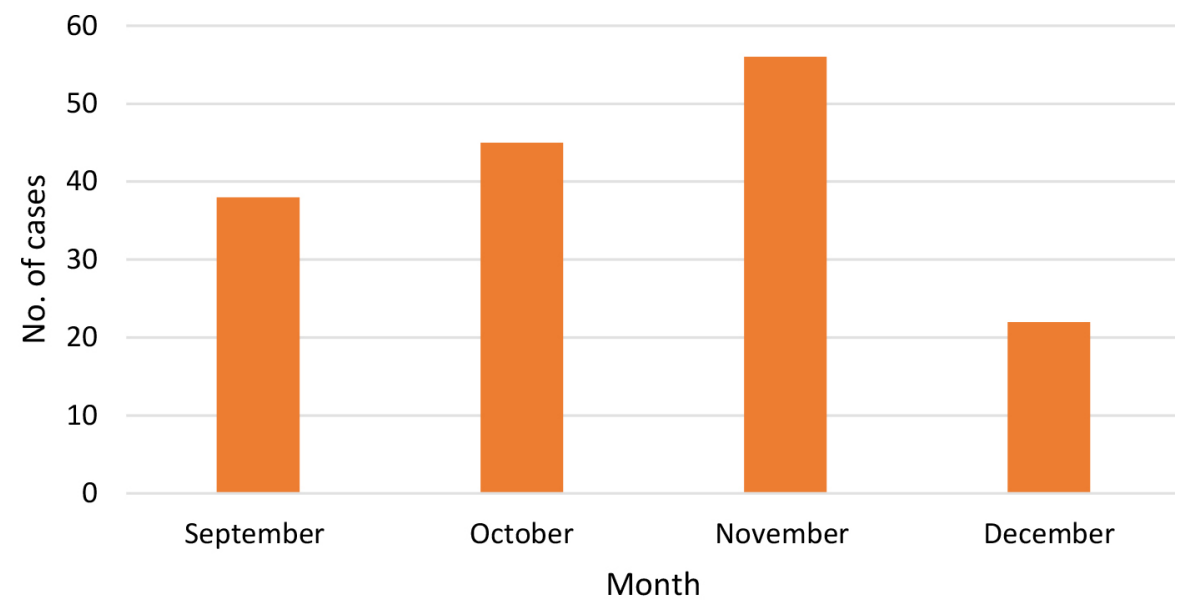

Figure 8 Death cases distribution by months for COVID 19 patients at the Alshifaa Center. 


\section{FUTURE PERSPECTIVES}

Iraq had big progress in the molecular level diagnosis of COVID-19; Iraq increased the molecular diagnostic labs from three laboratories in the whole country at the beginning of the pandemic ${ }^{7,8}$ to one laboratory at each governorate and more than five labs in Baghdad. The ministry of health is also permitting the private sector laboratories if they fulfill the requirements. Yet, Iraq still has no gene sequencing technique, which is widely used in many countries to detect new strains. Some central laboratories started using the qPCR kits that could detect the positive cases of new strains. ${ }^{7-9}$ Other than the gene sequencing, Iraq lacks techniques of neutralization techniques, clustered regularly interspaced short palindromic repeats, and CRISPR-associated protein 9 (CRISPR/Cas 9) to detect the virus strains. ${ }^{25}$ Instead, Iraq relies on the qPCR as the only technique to detect the virus.

On the level of the vaccines, Iraq used three types of COVID-19 vaccines in early 2021; namely, Sinopharm, AstraZeneca, and Pfizer. As witnesses, we can say that the Iraqi government is pushing the people hard to getting the vaccine and complying with the protection procedures.

\section{CONCLUSIONS}

A database of COVID-19 tests, infections, and mortality cases at the Alshifaa center for the period September $1^{s t}, 2020$ to December $31^{s t}$, 2020 was analyzed. The maximum and minimum numbers of infections and deaths were in November and December, respectively, where the infection and mortality rates of males were higher than females. Furthermore, as the age of patients increased, the chance of death increased in both genders. However, for males, a remarkable increase in mortality was at the age category of 61-65 years comparing with younger categories, while for females it was 56-60 years. Based on the data of this work, we can conclude that the peak of infection rate is similar to other countries. Hence, the number of checked children was negligible, while we have the peak among the 40s-50s years old patents. Also, females' death cases were less than males, which could be attributed to the genetic influence and higher responsibility that females showed to prevent the infection. Here, more researches are needed to come up with a comprehended description of the virus, this may help to elucidate and provide information about the virus's epidemiology.

\section{ACKNOWLEDGMENT}

The authors like to thank Alshifaa center at the Medical city/Baghdad for providing the data. 


\section{DECLARATIONS}

\section{Authors' contributions}

Conceptualization, investigation, writing-original draft: RR and MK. Data curation: EZA and WAA. Formal analysis: MK. Funding acquisition: N/A. Methodology: MK and NA. Project administration: IS. Resources: NH. Software: N/A. Supervision: EY. Validation: NA. Visualization: RR. writing-review \& editing: EY, NA, IS. All authors reviewed and approved the final draft before publication.

\section{Conflict of interest}

The authors have no conflict of interests to declare.

\section{Ethical approvals}

The study is based on analyzing statical data and did not use actual biosamples. The authors obtained the data with authorities' permission from the Alshifaa Healthcare Center.

\section{Data availability}

The authors obtained the data with authorities' permission from the Alshifaa Center.

\section{Funding resources}

None.

\section{REFERENCES}

1. Yang Y, Peng F, Wang R, Guan K, Jiang T, Xu G, et al. The deadly coronaviruses: The 2003 SARS pandemic and the 2020 novel coronavirus epidemic in China. J Autoimmun. 2020;109:102434. Available from: 10.1016/j.jaut.2020.102434.

2. Al-Mashhadani MH, Mohammed A, Raheem R, Yousif E. An overview: Coronaviruses in recent two decades. Al-Nahrain J Sci. 2021;2021(5):13-16. Available from: 10.22401/ANJS.00.5.03.

3. Hadi AG, Kadhom M, Hairunisa N, Yousif E, Mohammed SA. A review on COVID19: Origin, spread, symptoms, treatment, and prevention. Biointerface Res Appl Chem. 2020;10:7234-7242. Available from: 10.33263/BRIAC106.72347242.

4. Marx S, Kümmerer BM, Grützner C, Kato H, Schlee M, Bartok E, et al. RIG-Iinduced innate antiviral immunity protects mice from lethal SARS-CoV-2 infection. bioRxiv. 2021;Available from: 10.1101/2021.08.06.455405.

5. Tobaiqy M, Qashqary M, Al-Dahery S, Mujallad A, Hershan AA, Kamal MA, et al. Therapeutic management of COVID-19 patients: a systematic review. Infect Prev Pract. 2020;2(3):100061. Available from: 10.1016/j.infpip.2020.100061.

6. Forni G, Mantovani A. COVID-19 vaccines: where we stand and challenges ahead. Cell Death Differ. 2021;28(2):626-639. Available from: 10.1038/s41418-020-00720- 
9.

7. Al-Dahhan WH, Al-Mashhadani MH, Raheem R, Yousif E. Iraq Faces the COVID19 with Limited Health Capabilities and Major Medical Challenges. Bionatura: Latin American Journal of Biotechnology and Life Sciences. 2020;5:1271-1274. Available from: 10.21931/RB/2020.05.03.19.

8. Alsayed R, Ali AA, Makia R, Kadhom M, Raheem R, Al-Obaidi O, et al. Challenges facing Iraq to tackle the spread of COVID-19: An overview. J Univ Anbar Pure Sci. 2020;14:22-27.

9. Raheem R, Kadhom M, Alhashimie EZ, Alrubayee WA, Albayati N. A clinicalstatistical study on COVID-19 cases in Iraq: A case study. Al-Nahrain J Sci. 2021;5(Special issue):6-12. Available from: 10.22401/ANJS.00.5.02.

10. Iraqi Ministry of Planning;. Available from: https://mop.gov.iq.

11. Jin JM, Bai P, He W, Wu F, Liu XF, Han DM, et al. Gender differences in patients with COVID-19: Focus on severity and mortality. Front Public Health. 2020;8:152. Available from: 10.3389/fpubh.2020.00152.

12. Davies NG, Klepac P, Liu Y, Prem K, Jit M, Eggo RM. Age-dependent effects in the transmission and control of COVID-19 epidemics. Nat Med. 2020;26(8):1205-1211. Available from: 10.1038/s41591-020-0962-9.

13. Hadi AG, Kadhom M, Yousif E, Hairunisa N. In COVID-19 time, how to protect myself and others? a review. J Biomedika Kesehat. 2020;3(3):153-158. Available from: 10.18051/JBiomedKes.2020.v3.153-158.

14. Alsayed R, Kadhom M, Yousif E, Sabir DK. An epidemiological characteristic of the COVID-19 among children. Lett Appl NanoBioScience. 2020;9:1156-1164. Available from: 10.33263/LIANBS93.11561164.

15. Bunyavanich S, Do A, Vicencio A. Nasal gene expression of angiotensin-converting enzyme 2 in children and adults. JAMA. 2020;323(23):2427-2429. Available from: 10.1001/jama.2020.8707.

16. Dijkman R, Jebbink MF, Gaunt E, Rossen JWA, Templeton KE, Kuijpers TW, et al. The dominance of human coronavirus OC43 and NL63 infections in infants. J Clin Virol. 2012;53(2):135-139. Available from: 10.1016/j.jcv.2011.11.011.

17. Wong LSY, Loo EXL, Kang AYH, Lau HX, Tambyah PA, Tham EH. Age-related differences in immunological responses to SARS-CoV-2. J Allergy Clin Immunol Pract. 2020;8(10):3251-3258. Available from: 10.1016/j.jaip.2020.08.026.

18. Elgendy IY, Pepine CJ. Why are women better protected from COVID-19: Clues for men? Sex and COVID-19. Int J Cardiol. 2020;5(26):105-106. Available from: 10.1016/j.ijcard.2020.05.026.

19. Ghazeeri G, Abdullah L, Abbas O. Immunological differences in women compared with men: overview and contributing factors. Am J Reprod Immunol. 2011;66(3):163-169. Available from: 10.1111/j.1600-0897.2011.01052.x.

20. Hoffmann M, Kleine-Weber H, Schroeder S, Krüger N, Herrler T, Erichsen S, et al. SARS-CoV-2 cell entry depends on ACE2 and TMPRSS2 and is blocked by a clinically proven protease inhibitor. Cell. 2020;181(2):271-280. Available from: 


\subsection{6/j.cell.2020.02.052.}

21. Albayati N, Waisi B, Al-Furaiji M, Kadhom M, Alalwan H. Effect of COVID-19 on air quality and pollution in different countries. J Transp Health. 2021;21:101061. Available from: 10.1016/j.jth.2021.101061.

22. Patel VB, Zhong JC, Grant MB, Oudit GY. Role of the ACE2/angiotensin 1-7 axis of the renin-angiotensin system in heart failure. Cir Res. 2016;118(8):1313-1326. Available from: 10.1161/CIRCRESAHA.116.307708.

23. Burchill LJ, Velkoska E, Dean RG, Griggs K, Patel SK, Burrell LM. Combination renin-angiotensin system blockade and angiotensin-converting enzyme 2 in experimental myocardial infarction: implications for future therapeutic directions. Clin Sci (Lond). 2012;123(11):649-658. Available from: 10.1042/CS20120162.

24. Patel SK, Velkoska E, Burrell LM. Emerging markers in cardiovascular disease: Where does angiotensin-converting enzyme 2 fit in? Clin Exp Pharmacol Physiol. 2013;40(8):551-559. Available from: 10.1111/1440-1681.12069.

25. Ganbaatar U, Liu C. CRISPR-based COVID-19 testing: toward next-generation point-of-care diagnostics. Front Cell Infect Microbiol. 2021;11:663949. Available from: 10.3389/fcimb.2021.663949. 